\title{
THE INFLUENCE OF DIRECT COMPENSATION AND INDIRECT COMPENSATION TOWARD EMPLOYEE PERFORMANCE IN PT TRISUN ABADI MANDIRI
}

\author{
$1^{\text {st }}$ Iis Niar \\ Departement Of Applied Business Administration \\ Batam State Polytechnic \\ Batam City, Riau Island Indonesia \\ Iisniar217@gmail.com
}

\author{
$2^{\text {nd }}$ Nur Rahmah Andayani, S.IP.,M.Si \\ Departement Of Applied Business Administration \\ Batam State Polytechnic \\ Batam City, Riau Island Indonesia \\ Nunun@polibatam.ac.id
}

\begin{abstract}
This research aims to examine the influence of direct compensation and indirect compensation toward employee performance. The population in this research were all employees of PT Trisun Abadi Mandiri and the samples were taken by using non-probability sampling technique with saturated sampling and a sample of 50 people. Data was collected by distributing the questionnaires and tested by using multiple linear regression analysis techniques. The results of this research indicate that; 1) Direct compensation has a postive influence and does not have a significant influence toward employee performance, 2) Indirect compensation has a positive influence and has a significant influence toward employee performance, 3) Direct compensation and indirect compensation simultaneously have a positive and significant influence toward employee performance.
\end{abstract}

Keywords-Performance, Direct Compensation, Indirect compensation

\section{INTRODUCTION}

\section{A. Background}

Business competition in the current era of globalization is very tight. As we know at the end of 2015, the growth of the MEA (Asean Economic Community), which was opened for trade in goods, services and labor made the competition tighter because of the increasingly diverse demands of the market, companies must be able to compete with other companies. The company will ask employees to provide their energy and mind by carrying out their duties and responsibilities correctly and in accordance with the existing period in the company's provisions. Therefore the company must also be able to give attention and care for the welfare of employees. Employee welfare can also make reference and motivation in improving employee performance to achieve these goals. Performance is a real behavior that is displayed by every employee who works in a company in the form of work performance by employees produced in accordance with their responsibilities within the company In PT Trisun Abadi Mandiri, there are some employees who are still not satisfied with the compensation received for the results of their performance. This may be influenced by several factors from the company that determine the difference in salaries and wages of employees, i.e., employees who have skill level, craft level, and educational background. Likewise, the compensation payment might be not on time due to several constraints in the company finance. As of th employee performance will decrease and also have a negative impact on the company. These factors, have an effect on the decreased employee peformance results. The work and project should have been completed on time, eventually the project was postponed temporarily because the compensation payment was not paid on time.

Problems in providing compensation have also occurred in Batam, the influencecaused a demonstrations and strikes.

\section{B. Formulation of the problem}

Based on the above background, the main problems that will be discussed are as follows:

1) How far is the influence of direct compensation toward employee performance in PT Trisun Abadi Mandiri?

2) How far is the indirect compensation toward employee performance in PT Trisun Abadi Mandiri?

3) How far is the direct compensation and indirect compensation simultaneously toward employee performance in PT Trisun Abadi Mandiri? 


\section{Objective of the Study}

Based on the formulation of the problem above, the purpose to be achieved in this study are as follows:

1) Knowing the extent of direct compensation influence toward employee performance in PT Trisun Abadi Mandiri.

2) Knowing the extent of indirect compensation influence toward employee performance in PT Trisun Abadi Mandiri.

3) Knowing the extent of direct compensation and indirect compensation influence simultaneously toward employee performance in PT Trisun Abadi Mandiri.

\section{Significance of the study}

As for the benefits obtained from the research conducted by researchers are as follows:

\section{1) Practical Benefits}

This research is expected to be useful for the company that might be an input in the form of all the employees in giving direct and indirect compensation toward employee performance in PT Trisun Abadi Mandiri.

\section{2) Theoretical Benefits}

For the readers, this research can be an input and research reference and study of human resource management.

For the author, this research can be a reference in the application of science about the issue of direct and indirect compensation toward employee performance.

\section{REVIEW OF LITERATURE}

\section{A. Theoritical Framework}

1) Compensation

According to [3] stated that compensation is an employee that receives recompense in the form of salary or wages from the work they have provided for the company, both from thinking and the energy as well.

\section{2) Compensation Components}

Components are divided into two, i.e.,:

- Direct Compensation

According [2] Direct compensation, is rewards and warranty are given to employees because of a direct relationship with work in the form of salary / wages or incentives. Direct compensation is referred to as the rights obtained by the employee and the obligation to pay is the company, salary, incentives, wages paid to employees.

- Indirect Compensation

According to [4] Indirect compensation given to employees by repaying their services by providing insurance, benefits, leaves, facilities and so on.

\section{3) Employee Performance}

According to [8] Performance is a real behavior that is displayed by every employee who works in a company in the form of work performance by employees in accordance with their responsibilities in the company. According to [5] there are five indicators measuring employee performance are quality work, timeliness of employees, initiative, ability and communication.

\section{B. Mind Framework}

An illustration of the relationship between research variables, the theory that is made will be shown in the following figure, (X1) Direct compensation, (X2) Indirect Compensation, (Y) Employee Performance:

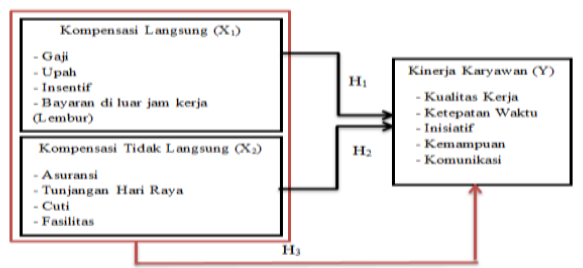

Fig 1. Conceptual Framework Source: Research developed, 2019

\section{METHODS OF RESEARCH}

A. Research Design

According to [6] The design in this research is quantitive research.The data was collected by using techniques whic distributing questionnaires.

\section{B. Population and Sample}

According to [6] The population of this research is 50 employees of PT Trisun Abadi Mandiri. The samples were taken by using nonprobability sampling techiniques with a saturated sampling. Saturated sampling, in determining the samples by taking all of the population as respondents.

C. Operational Variables

The definition of research operational variables is an explanation of each the variables used in the study of indicators are shape it. The definition of operational research can be seen in the following table this:

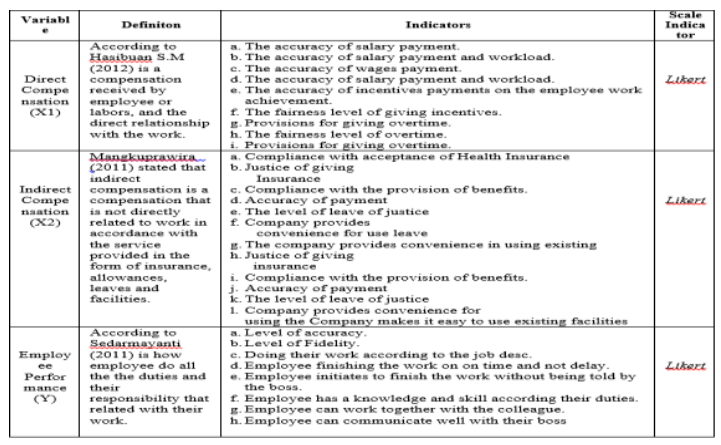

Fig. 1. Operational Definition of the Research Variable 


\section{Validity and Reliability}

A questionnaire is said to be valid if the statement on the questionnaire is able to reveal something that will be measured by the questionnaire. The testing technique most often used by researchers to test the validity or validity level is to use Bivariate Pearson correlation (Pearson Moment Products). If the results of rtable $<r$ count, then it can be stated that the instrument is valid. Whereas, if rtable> $r$ hitung then it is invalid.

According to [6] Reliability shows consistency whether the questionnaire can be used more than once. Because an instrument results are said to be reliable if there are similarities in the results of the data even though in different research times. And to find out the value of instrument reliability or test in the form of a questionnaire answer, Cronbach Alpha method with Cronbach alpha criteria> 0.60 if the results obtained from the test meet the criteria, it can be stated that the instrument used is reliable.

\section{E. Data analysis method}

- Normality Test is a condition of normal distribution in independent and dependent variables.

- Test of Autocorrelation that will be used to detect a situation where there is a correlation between the error variables.

- Multicollinearity Test is a test used to test the existence of relationships between independent variables.

- Heteroskesdastisitas test which can be used to detect the error variance condition one with another error different.

\section{F. Test of Multiple Regression Analysis}

This analysis technique is used for measuring instruments between the influence variables by two or more independent variables $(\mathrm{X})$ with the dependent variable $(\mathrm{Y})$ where the independent variables in this study are direct and indirect compensation while the dependent variable is aemployee performance.

\section{G. Hypothesis testing}

\section{- T test (Partial Test)}

The $t$ test or partial test is used to measure the level of influence between the independent variables on the dependent variable.

- F test (Simultan Test)

The F test or the simultaneous test is used to determine the effect of the independent variables simultaneously on the dependent variable which will be examined at a significant level of $5 \%$.

\section{H. Time and Place of Research}

The research will be conducted at PT Trisun Abadi Mandiri.

\section{RESULTS AND DISCUSSSION}
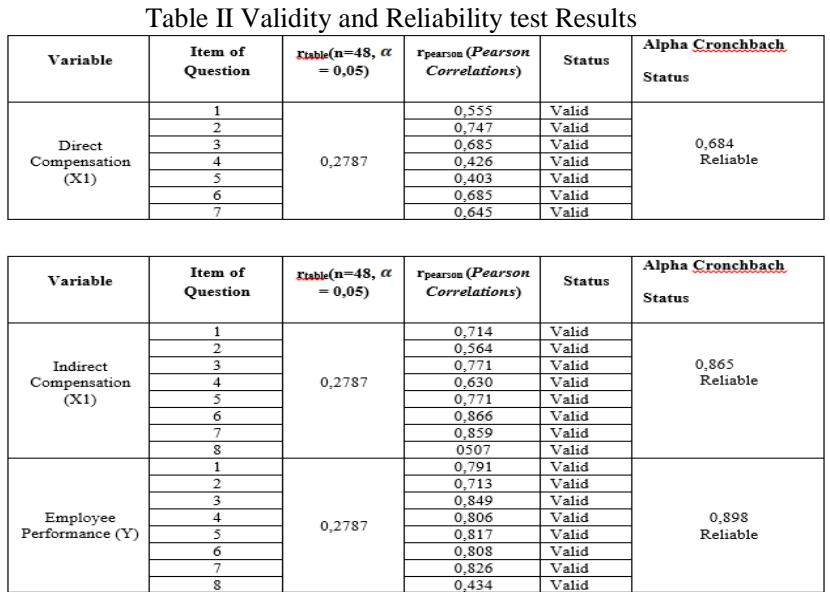

Source: Research developed, 2019

Based on the table 3 can be known that each of the $r$ pearson of each question in each variables shows the significant result and shows that $r$ pearson $>r$ table. The result of rtable obtained by number of $n=48$ on the significant level 0,05 (two tailed test) so that the numbers are obtained is 0.2787 and stated valid.

From the table above can be know that indirect compensaton variable (X1) Value has a cronbach alpha coeficients 0.684 , indirect compensation variable (X2) is 0.865 , and employee performance variable $(\mathrm{Y})$ is 0.898 that shows the result is above 0.60 . So, the table can be measured as reliable.

\section{A. Normality Test Results}

The data in this research is using Kolmogorv-Smirnov test. Data can be admitted as normal if Kolmogorv-smirnov $\mathrm{z}<\mathrm{z}$ table, or by using probability sig value ( 2 tailed) $>\mathrm{a}$, sig $>0.05$. The result of the test obtained in table 4 as follow:

Table III Normality test Results

\begin{tabular}{|l|l|}
\hline Uji Kolmogrov-Smirnov & Standardized Residual \\
\hline Kolmogorov-Smirnov Z & 0,679 \\
\hline Sig. (2-tailed) & 0,745 \\
\hline
\end{tabular}

Source: Research developed, 2019

The result shows that the data has a significant level of 0.745 shos that the obtained level of significant $>0.05$. Thus the data analyzed in this study is normally distributed.

From Figure 2, the normal P-P plot has the presence of points around the direction of the diagonal line, thus the data can be said to have a normal distribution. 


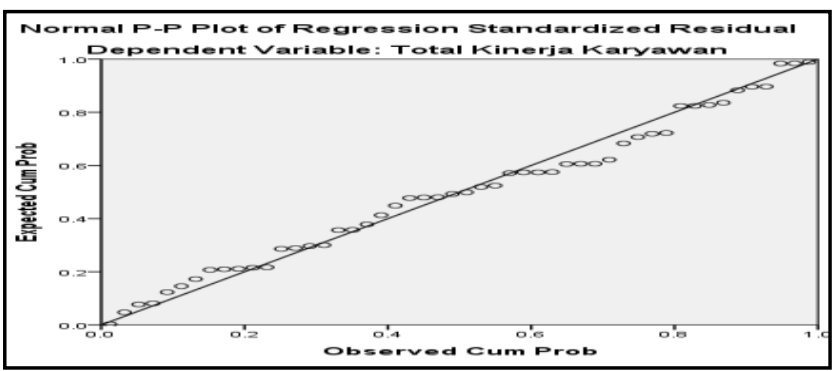

Fig. 2. P-PLOT

Source: Research developed, 2019

\section{B. Multicolinerity Test Results}

With the correlation matrix and VIF value and the tolerance value $>0.1$ and VIF $<10.0$ it shows no symptoms of multicollinearity.

Table IV Multicollinearity test results

\begin{tabular}{|l|c|c|}
\hline \multirow{2}{*}{ Variabel } & \multicolumn{2}{|c|}{ Collinearity Statistics } \\
\cline { 2 - 3 } & Tolerance & VIF \\
\hline Direct Compensation (X1) & 0,977 & 1.023 \\
\hline $\begin{array}{l}\text { Indirect Compensation } \\
\text { (X2) }\end{array}$ & 0,977 & 1.023 \\
\hline
\end{tabular}

Source: Research developed, 2019

The table above shows that tolerance of direct compensation (X1) has a value of 0.977 and $>0.1$ and VIF value <from 10.0 which is 1.023 . Indirect compensation variable (X2) has a tolerance value of 0.977 which means that it is greater than 0.1 and the VIF value is less than 10.0 which is 1.023 . So, from these data states that for this study the regression equation did not occur in the presence of multicollinearity.

\section{Heteroscedasticity Test Results}

If regression variance occurs inequality. In this research using the Glejser test. If it has a significant value greater (>) than 0.05 , it can be concluded that the regression has no symptoms of heteroscedasticity.

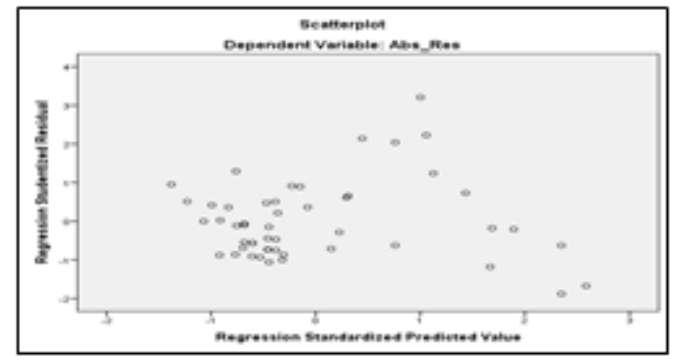

Fig. 3. Heteroscedasticity test results

Source: Research developed, 2019

If seen from the Scatterplot graph in Figure 3 above, there is a spread and irregular pattern, so that it can be said in this study that there is no heteroscedasticity
Table V Heteroscedasticity Result

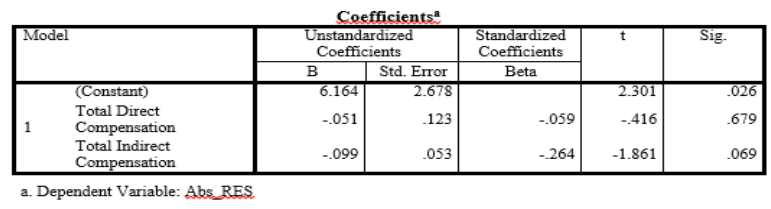

Source: Research developed, 2019

Table 6 is also strengthened through the Glejser test that the two variables do not occur heteroscedasticity. Direct compensation variable has a significant value of 0.679> 0.05 . Then on the indirect compensation variable with a significant value of $0.069>0.05$. Seen the two variables above have a significant value $>0.05$.

\section{Multiple Linear Regression Test Results}

In the previous test results prove that the equation model that was submitted in the study has met the requirements. The results of multiple linear regression testing below:

Table VI Multiple Linear Regression Test Results

\begin{tabular}{|c|c|c|c|c|c|}
\hline & & Coefficie & & & \\
\hline \multirow[t]{2}{*}{ Model } & \multicolumn{2}{|c|}{ Unstandardized Coefficients } & $\begin{array}{l}\text { Standardized } \\
\text { Coefficients }\end{array}$ & \multirow[t]{2}{*}{$\bar{t}$} & \multirow[t]{2}{*}{ Sig. } \\
\hline & B & Std. Error & Beta & & \\
\hline (Constant) & 2.031 & 4.225 & & .481 & .633 \\
\hline $\begin{array}{l}\text { Direct } \\
\text { Compensation }\end{array}$ & .009 & .194 & .004 & .049 & .961 \\
\hline $\begin{array}{l}\text { Indirect } \\
\text { Compensation }\end{array}$ & .861 & .084 & .835 & 10.300 & .000 \\
\hline
\end{tabular}

Source: Research developed, 2019

The regression equation that occurs can be expressed by using multiple linear regression formulas as follows:

$$
Y^{\prime}=2,031+0,009\left(X_{1}\right)+0,861\left(X_{2}\right)
$$

Some things that can be known from the equation are as follows:

- Constants of 2.031 which means that if the direct compensation variable and also the indirect compensation variable value is 0.633 , the employee's performance is said to be 2.031 .

- Direct Compensation Variables with 0.009 coefficient and positive value, if it is assumed that there is an increase in product quality variables then the constants will be able to increase consumer decisions by 0.009 which means that the more direct compensation, the higher the employee's performance.

- Direct Compensation variable has a coefficient of 0.861 and a positive value, if it is assumed there is an increase in indirect compensation variables, the constants will increase consumer decisions by 0.861 , which means the better the indirect compensation given, the better the performance value of employees. 


\section{E. Hypothesis Testing}

- $\quad$ T test (Partial)

It has the purpose of confirming the hypothesis separately. This $\mathrm{T}$ test is seen from the magnitude of the value then compared with the significance level $\alpha$ $=5 \%$. To find the value of table can be searched using the degree of freedom formula as follows:

$\mathrm{df}=50-3$

$\mathrm{df}=47$ so that the $\mathrm{t}$ table value is 1678 .

The results of data processing are known where thitung is $0.049<\mathrm{t}$ table 1.678 and Sig value is $0.961>$ 0.05 . It was concluded that direct compensation variables had a non-significant effect on employee performance. And the indirect compensation variable has a significant influence on employee performance. employee performance with the results of the calculation of tcount 2.901> t table 1.678 with a significant value level of $0.000<0.05$.

- F test (Simultaneous)

From the results of the simultaneous test it can be concluded that the value of Fcount> Ftable is known by the Fcount data of 54,369 and Ftable of 3,19 which means the direct compensation variable and indirect compensation have a significant influence on employee performance.

\section{CONCLUSIONS \& RECOMMENDATIONS}

\section{A. Conclusions}

Based on the results of this study, it can be concluded that:

- Direct compensation has a positive and not significant influence toward employee performance in PT Trisun Abadi Mandiri.

- Indirect Compensation has a positive and significant influence toward employee performance in PT Trisun Abadi Mandiri.

- Direct and indirect compensation simultaneously have a positive and significant influence toward employee performance in PT Trisun Abadi Mandiri.

\section{B. Recommendation}

Based on the results of the research conducted by the researchers, the suggestions that the researchers convey are:

- Provision of direct compensation The company should take into account the physiological needs of employees in providing salary and incentives appropriately and fairly. Because in this study, there are still those who disagree with the indicators that show that statement is the X1.5 indicator, namely "The company provides incentives for the given performance is right and fair" with an average value of 2.46 .

- The provision of indirect compensation should companies provide and pay attention to the rights of facilities such as parking lots and uniforms that are fair and in accordance with each department. For the employee's annual leave permit, the company should be able to socialize so that employees really understand.

- If employees lack knowledge and expertise, companies can provide training or expertise training in their respective fields.

\section{REFERENCES}

[1] Hasibuan, S. M (2012). Human Resource Management. Jakarta: PT Bumi Aksara.

[2] Hasibuan, S. M (2013). Human Resource Management. Jakarta: PT Bumi Aksara.

[3] Kadarisman. (2014). Compensation Management. Jakarta: RajawaliPers.

[4] Mangkuprawira, S. (2011). Strategic Human Resource Management. Second edition. Indonesia, Bogor: Ghalia.

[5] Sedarmayanti. (2011). Human Resource Management, Reformation and Management of Civil Servants.

[6] Sugiyono. (2014) .Research method quantitative qualitative and $R \&$ $D$. Bandung: Alfabeta.

[7] Wibowo, G., \& Setiawan, R. (2014). Effect of Financial and NonFinancial Compensation on Employee Performance at CV Sejahtera Car Surabaya. AGORA Journal Vol. 2, No.1, 1-10.

[8] Yani, H. (2012). Human Resource Management. Jakarta: Mitra Wacana Media. 